\title{
A pilot study on the immunogenicity of dendritic cell vaccination during adjuvant oxaliplatin/capecitabine chemotherapy in colon cancer patients
}

\author{
WJ Lesterhuis', IJM de Vries ${ }^{2}$, EA Aarntzen', A de Boer ${ }^{2}$, NM Scharenborg ${ }^{2}$, M van de Rakt ${ }^{2}$, D-J van Spronsen ${ }^{3}$, \\ FW Preijers ${ }^{4}$, CG Figdor ${ }^{2}$, GJ Adema ${ }^{2}$ and CJA Punt ${ }^{*, I}$ \\ 'Department of Medical Oncology, Radboud University Nijmegen Medical Centre, PO Box 910I, Nijmegen 6500 HB, The Netherlands; ${ }^{2}$ Department \\ of Tumor Immunology, Nijmegen Centre for Molecular Life Sciences, Radboud University Nijmegen Medical Centre, PO Box 9 I 0 I, Nijmegen 6500 HB, \\ The Netherlands; ${ }^{3}$ Department of Internal Medicine, Canisius Wilhelmina Hospital Nijmegen, PO Box 90I 5, Nijmegen 6500 GS, The Netherlands; \\ ${ }^{4}$ Laboratory of Hematology, Department of Laboratory Medicine, Radboud University Nijmegen Medical Centre, PO Box 9101 , Nijmegen 6500 HB, \\ The Netherlands
}

\begin{abstract}
BACKGROUND: Dendritic cell (DC) vaccination has been shown to induce anti-tumour immune responses in cancer patients, but so far its clinical efficacy is limited. Recent evidence supports an immunogenic effect of cytotoxic chemotherapy. Pre-clinical data indicate that the combination of chemotherapy and immunotherapy may result in an enhanced anti-cancer activity. Most studies have focused on the immunogenic aspect of chemotherapy-induced cell death, but only few studies have investigated the effect of chemotherapeutic agents on the effector lymphocytes of the immune system.

METHODS: Here we investigated the effect of treatment with oxaliplatin and capecitabine on non-specific and specific DC vaccineinduced adaptive immune responses. Stage III colon cancer patients receiving standard adjuvant oxaliplatin/capecitabine chemotherapy were vaccinated at the same time with keyhole limpet haemocyanin (KLH) and carcinoembryonic antigen (CEA)peptide pulsed DCs.

RESULTS: In 4 out of 7 patients, functional CEA-specific T-cell responses were found at delayed type hypersensitivity (DTH) skin testing. In addition, we observed an enhanced non-specific T-cell reactivity upon oxaliplatin administration. KLH-specific T-cell responses remained unaffected by the chemotherapy, whereas B-cell responses were diminished.

CONCLUSION: The results strongly support further testing of the combined use of specific anti-tumour vaccination with oxaliplatinbased chemotherapy.

British Journal of Cancer (2010) 103, |4I5-|421. doi:I0.1038/sj.bjc.6605935 www.bjcancer.com

Published online 5 October 2010

(c) 2010 Cancer Research UK
\end{abstract}

Keywords: colon cancer; chemotherapy; dendritic cells; immunotherapy; oxaliplatin; vaccination

Until recently, the commonly held opinion was that chemotherapy and immunotherapy should not be combined because of the myelosuppressive effect of most cytotoxic agents. However, it has now become evident that chemotherapeutics can exhibit several beneficial effects on the immune system (Lake and Robinson, 2005). For example, treatment with gemcitabine results in increased antigen cross-presentation, $\mathrm{T}$ lymphocyte expansion and T-cell infiltration of tumours (Nowak et al, 2002), and 5 -fluorouracil (5-FU) has been described to upregulate tumour antigen expression on colorectal and breast cancer cells (Correale et al, 2003). Furthermore, suppressive regulatory $\mathrm{T}$ cells are depleted by several chemotherapeutics also resulting in enhanced T-cell reactivity (Correale et al, 2005a; Ghiringhelli et al, 2007). In addition, treatment with non-myeloablative lymphodepleting chemotherapy results not only in reduced regulatory $\mathrm{T}$-cell frequencies, but also provides 'space' in the bone marrow for

*Correspondence: Dr CJA Punt; E-mail: c.punt@onco.umcn.nl Received I8 June 20 I0; revised I September 2010; accepted 7 September 20।0; published online 5 October 2010 naive $\mathrm{T}$ cells to proliferate upon adoptive $\mathrm{T}$-cell transfusion (Dudley et al, 2002). Using this strategy, significant clinical results have been obtained in metastatic melanoma patients (Dudley et al, 2005). Pioneering work by Zitvogel and colleagues has shown that the cytotoxic agents oxaliplatin and doxorubicin induce immunogenic cell death, as upon treatment with these agents, tumour cells transport calreticulin to their cell surface. The exposure of calreticulin provides a signal that is recognised by dendritic cells (DCs) and ultimately results in phagocytosis of the tumour cells (Obeid et al, 2007). Exposure of tumour cells to oxaliplatin results in the release of high mobility group box 1 (HMGB1) protein, that activates DCs in a toll-like receptor-4 (TLR4)-dependent manner (Apetoh et al, 2007). The clinical impact of this immune pathway in colorectal cancer patients is emphasised by the recent observation that patients carrying the TLR4 loss-of function allele Asp299Gly exhibit reduced progression-free and overall survival in response to oxaliplatin as compared with patients carrying the normal TLR4 allele (Tesniere et al, 2009).

Previous studies in animal models provide a rationale for the combination of chemotherapy and immunotherapy in colon cancer. In a murine model, T-cell responses against the colon 
cancer-associated antigen thymidylate synthase that were induced by a peptide vaccine were not hampered by the administration of 5 -FU. The combination of peptide vaccination and 5-FU resulted in a significant delay in tumour growth as compared with treatment with peptide or 5-FU alone (Correale et al, 2005b). Similarly, it was shown in a murine colon cancer model that the addition of 5-FU/leucovorin or irinotecan to bone marrow-derived DC vaccination did not diminish the immunogenicity of the vaccine (Bourquin et al, 2006). Small proof-of-concept clinical trials in cancer patients indicate that the efficacy of anti-cancer vaccines may indeed be enhanced by chemotherapy (Kaufman et al, 2008; Nistico et al, 2008), however additional studies on scheduling and appropriate combinations are warranted.

Platinum-based chemotherapy represents a cornerstone in the systemic treatment of many types of cancer (Desoize and Madoulet, 2002). Besides their direct cytotoxic effects, platinum anti-cancer drugs may also exert their clinical effect through indirect activation of the immune system via induction of immunogenic tumour cell death (Apetoh et al, 2007; Obeid et al, 2007; Tesniere et al, 2009). Most studies however, mainly focused on the effect of chemotherapy on tumour cells and antigenpresenting cells. Little attention has been paid to the effect of chemotherapy on the effector lymphocytes of the immune system. Although neutropenia is a common side effect of chemotherapy in the treatment of solid tumours, lymphopenia is rarely observed. A stimulatory effect of chemotherapy on tumour immunogenicity without impairing immune effector cell function would provide a strong rationale to develop novel chemoimmunotherapeutic strategies. For this reason, we investigated whether an oxaliplatinbased chemotherapy regimen combined with antigen-specific vaccination in cancer patients can result in tumour antigenspecific immune reactivity.

\section{PATIENTS AND METHODS}

\section{Study design}

This was an open-label, single-institution, single-arm exploratory study in which patients with stage III colon cancer received adjuvant treatment with monocyte-derived mature DCs loaded with carcinoembryonic antigen (CEA)-peptide in combination with standard oxaliplatin/capecitabine chemotherapy. Approval from the local regulatory committee was obtained.

\section{Objectives}

The primary end point was to assess the immunogenicity of the vaccine during oaxaliplatin/capecitabine chemotherapy. Secondary end points were the toxicity and the feasibility of CEA-specific vaccination in colon cancer patients, during chemotherapy.

\section{Patients}

Inclusion criteria included: patients with stage III colon cancer, HLA-A0201 phenotype, ECOG performance status $0-1$, age above 18 years, initiation of adjuvant chemotherapy $<8$ weeks since surgery for the primary tumor, no previous chemotherapy, adequate bone marrow, kidney and hepatic function and written informed consent. Exclusion criteria included: the use of immunosuppressive drugs, a history of second malignancy and other serious concomitant diseases preventing the safe administration of study drugs or likely to interfere with the study end points.

\section{DC preparation}

DCs were generated as described previously (de Vries et al, 2005b; Lesterhuis et al, 2006). Peripheral blood mononuclear cells
(PBMC) were isolated by PureCell (Medicult, Jyllinge, Denmark) density gradient centrifugation $\left(30 \mathrm{~min}, 4^{\circ} \mathrm{C}, 2100\right.$ r.p.m. $)$, adherent monocytes were cultured in Cellgro medium enriched with $500 \mathrm{U} \mathrm{ml}^{-1}$ interleukin- 4 and $800 \mathrm{U} \mathrm{ml}^{-1}$ granulocyte macrophage colony stimulating factor ( all CellGenix, Freiburg, Germany). KLH $\left(10 \mu \mathrm{g} \mathrm{ml}^{-1}\right.$, Calbiochem, San Diego, CA, USA) was added at day 3 of culture and 2 days before harvesting, we added the maturation cocktail (prostaglandin $\mathrm{E}_{2}$ (Pharmacia \& Upjohn, Puurs, Belgium, $\left.10 \mu \mathrm{g} \mathrm{ml}^{-1}\right)$, tumor necrosis factor- $\alpha\left(10 \mathrm{ng} \mathrm{ml}^{-1}\right), \mathrm{IL}-1-\beta\left(5 \mathrm{~g} \mathrm{ml}^{-1}\right)$ and IL-6 (15 $\mathrm{ng} \mathrm{ml}^{-1}$, all CellGenix)).

Cells were harvested at day 7 and part of the cells were loaded with peptide and put in a syringe for immediate vaccination; the remaining cells were frozen for the second and third vaccination and the delayed type hypersensitivity (DTH) (de Vries et al, 2002). Of each batch of patient DCs, a sample was used for quality control. Release criteria were as previously described (Figdor et al, 2004).

DCs were pulsed with the wild type CEA-peptide CAP-1 $\left(\mathrm{CEA}_{571-579}\right.$, YLSGANLNL, Clinalfa, Bubendorf, Switzerland) (Tsang et al, 1995) directly after harvesting or after thawing (de Vries et al, 2002, 2003).

\section{Treatment schedule}

Patients received eight cycles of oral capecitabine $2000 \mathrm{mg} \mathrm{m}^{-2}$ at days $1-14$ and oxaliplatin $130 \mathrm{mg} \mathrm{m}^{-2}$ intravenously at day 1 . Cycles were repeated every 3 weeks. Before the first cycle, patients underwent a leukapheresis for collection of PBMCs for the DC culture. At days 4,10 and 17 of the first cycle of chemotherapy patients received three vaccinations intradermally (i.d.) and intravenously (i.v.; $5 \times 106$ i.d./10 $\times 106$ i.v.) with CEA-peptide loaded dendritic cells (Figure 1). In pre-clinical models it has been shown that i.v. administered DCs provide a better anti-tumour response against visceral metastases, whereas non-visceral metastases respond better to i.d. administered DCs (Mullins et al, 2003). As both lymphogenous and haematogenous spreading occurs in colorectal cancer, we chose to combine both routes of administration. After completion of the vaccinations a DTH skin test was performed on day 19 , followed by biopsies of DTH injection sites on day 22. Dexamethasone was not administered as anti-emetic prophylaxis during the first cycle.

\section{Immunologic monitoring}

Analysis of peripheral blood immune cell subsets Within the CD45 + leukocyte population, PBMCs were stained with antibodies against CD14, CD19, CD3, CD8, CD4 and CD56 (for distinction of monocytes, $\mathrm{B}$ cells, $\mathrm{T}$ cells, CTLs, $\mathrm{T}$ helper

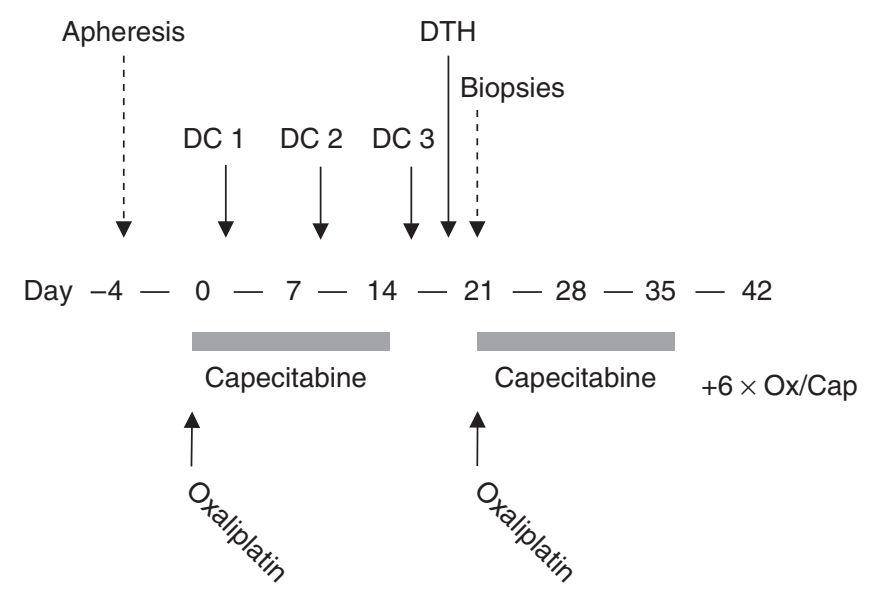

Figure I Treatment schedule. 
lymphocytes and NK cells, respectively). After washing, the samples were analysed by flowcytometry.

Monitoring of non-specific T-cell stimulatory capacity Peripheral blood mononuclear cells were obtained by density-gradient centrifugation at days $1,4,10,17$ and 22 . Cells were plated in 96-well U-bottom plates, $2 \times 10^{5}$ per well, in RPMI/human serum of $5 \%$ and phytohaemagglutinin (PHA) was added $\left(1 \mu \mathrm{g} \mathrm{ml}^{-1}\right)$. After $24 \mathrm{~h}$, supernatant was harvested for cytokine production analysis. After 3 days, $1 \mu \mathrm{Ci}$ per well of $3 \mathrm{H}$-thymidine was added to the culture for $8 \mathrm{~h}$, after which proliferation was stopped by storing the culture plate at $-20^{\circ} \mathrm{C}$. Incorporation of $3 \mathrm{H}$-thymidine was measured in a $\beta$-counter. The index was calculated as the counts ratio between PHA-stimulated PBMC and non-stimulated PBMC.

Monitoring of KLH-specific CD4 + T-cell responses $\mathrm{CD} 4+\mathrm{T}$-cell responses against $\mathrm{KLH}$ were measured using a $3 \mathrm{H}$-thymidine incorporation proliferation assay with PBMCs of the patients at days $1,4,10,17$ and 22 . The index was calculated as the counts ratio between KLH-stimulated PBMCs and non-stimulated PBMCs.

Delayed type hypersensitivity reactions Post-treatment DTH reactions were performed as described previously (de Vries et al, 2005a). Briefly, CEA-peptide alone $(100 \mu \mathrm{g}$ in $100 \mu \mathrm{l})$, DCs pulsed with CEA-peptide, DCs pulsed with KLH and CEA-peptide and DCs pulsed with KLH alone $\left(0.4-5 \times 10^{5}\right.$ DCs each in $\sim 100-200 \mu \mathrm{l}$ ) were injected i.d., $5-10 \mathrm{~cm}$ from an inguinal lymph node at different sites, in the back of the patients. The maximum diameter of induration was measured after $48 \mathrm{~h}$. T-cell culture from DTH biopsies was performed in low dose IL-2 (Proleukin, Chiron, the Netherlands $100 \mathrm{U} \mathrm{ml}^{-1}$ ) for $\sim 2$ weeks without ex vivo re-stimulation with antigen as described before (de Vries et al, 2005a)

MHC tetramer staining DTH-derived cells $\left(1 \times 10^{5}\right.$ cells in $\left.10 \mu \mathrm{l}\right)$ or PBMCs $\left(1 \times 10^{6}\right.$ cells in $\left.10 \mu \mathrm{l}\right)$ were incubated with PE-labeled CEA and cytomegalovirus (CMV) tetrameric-MHC complexes (Sanquin, Amsterdam, the Netherlands) for $60 \mathrm{~min}$ at room temperature. In the last $20 \mathrm{~min}$ of this incubation, FITC-conjugated monoclonal antibodies directed against CD8 (Becton Dickinson, Breda, Netherlands) were added. After washing, the samples were analysed by flowcytometry. For peripheral blood at least $1 \times 10^{6}$ PBMCs were analysed and for DTH-infiltrating T cells all available cells were analysed. In all analyses, CEA tetramer staining was compared with CMV tetramers as a negative control.

Cytokine secretion Production of cytokines by the total population of DTH-derived cells was measured in response to T2 cells pulsed with CEA-peptide or an irrelevant HLA-A2.1 binding peptide (tyrosinase or G250). Cytokine production was measured in supernatants after $16 \mathrm{~h}$ by cytometric bead array (Th1/Th2 Cytokine CBA 1; BD Pharmingen, Breda, Netherlands). IFN- $\gamma$ production was considered positive when IFN- $\gamma$-levels of DTHinfiltrating $\mathrm{T}$ cells were more than 10 -fold higher after coincubation with CEA-loaded T2 cells compared with co-incubation with T2 cells loaded with irrelevant antigen.

\section{RESULTS}

\section{Patients and toxicity}

In all, seven patients were included in this study with a median age of 55 years (range 47-75). All patients had stage III colon cancer. Most patients experienced grade 1 fever and flu-like symptoms after vaccination. One patient had a grade 2 allergic reaction of unknown cause after two vaccinations, consisting of generalised exanthema with fever and pruritus for which he was treated with anti-histamines. The third vaccination was without symptoms. Other toxicities (grade 2 nausea/vomiting, one patient; grade 1 diarrhoea, one patient; grade 3 neurotoxicity, one patient) were considered to be related to the chemotherapy. With a follow-up of 10-35 months (median 18 months), all patients are recurrencefree.

\section{Peripheral blood subsets during treatment}

Peripheral blood frequencies of mononuclear cells did not significantly decrease during treatment with oxaliplatin/capecitabine (Figure 2, Supplementary Figure 1). The total number of $\mathrm{T}$ cells $(\mathrm{CD} 3+)$, $\mathrm{T}$ helper cells $(\mathrm{CD} 4+)$, cytotoxic $\mathrm{T}$ cells $(\mathrm{CD} 8+)$, B cells $(\mathrm{CD} 19+)$, monocytes $(\mathrm{CD} 14+)$ and natural killer cells $(\mathrm{CD} 3-/ \mathrm{CD} 56+)$ remained stable during chemotherapy.

\section{Non-specific immune reactivity during oxaliplatin/ capecitabine}

To test whether treatment with oxaliplatin/capecitabine affects overall $\mathrm{T}$-cell reactivity that could influence the efficacy of DC vaccination, we tested the PHA-induced T-cell proliferative response at different time points during treatment (Figure 3). Surprisingly, we found a striking increase in the proliferative capacity of peripheral blood $\mathrm{T}$ cells, in most cases directly after infusion of the oxaliplatin (Figure $3 \mathrm{~A}$ ). In addition, the IFN- $\gamma$ release upon PHA-stimulation increased (Figure $3 \mathrm{~B}$ ). As this has not been reported before or after DC vaccination, and as we also observed this in a control group of patients that were treated with platinum compounds alone (Supplementary Patients and methods and Supplementary Figure 2), we conclude that this is a platinum-effect and not due to the DC vaccine. When peripheral blood lymphocytes of three healthy donors were stimulated with PHA after $24 \mathrm{~h}$ of in vitro culture with oxaliplatin, we did not observe an enhanced effect of the platinum treatment (Supplementary Figure 3).

\section{KLH-specific immune responses during oxaliplatin/ capecitabine}

To test whether de novo antigen-specific $\mathrm{T}$ - and $\mathrm{B}$-cell immune responses can be induced during treatment with oxaliplatin and capecitabine, we loaded the DCs with the control antigen KLH and measured the proliferative $\mathrm{T}$-cell response and antibody response (Figure 4, Table 1). We observed a robust $\mathrm{CD} 4+$ proliferative response against KLH in all patients, comparable to previous studies in colorectal cancer and melanoma patients who were vaccinated with the same vaccine without chemotherapy (Figure 4A) (de Vries et al, 2003, 2005a; Lesterhuis et al, 2006). However, in all but two patients antibody responses against KLH were absent (Figure 3B). In the patients with an antibody response, this response was only weak. This is in contrast to our previous studies in which we could detect a response in almost all vaccinated patients (de Vries et al, 2003).

\section{Vaccine-induced CEA-specific immune responses during oxaliplatin/capecitabine}

We next determined the vaccine-induced tumor antigen-specific immune response in DTH biopsies as previously published (de Vries et al, 2005a; De Vries et al, 2007). In four out of seven patients, we found CEA-specific $\mathrm{T}$ cells by means of tetramer analysis (Figure 5A, Table 1). In a previous cohort of colorectal cancer patients that were treated with the same vaccine without chemotherapy, we found CEA-specific DTH-infiltrating T cells in 5 out of 11 patients after one vaccination cycle (Lesterhuis et al, 2006). Thus, the efficacy of the vaccine does not seem to be negatively influenced by chemotherapy in terms of the induction 

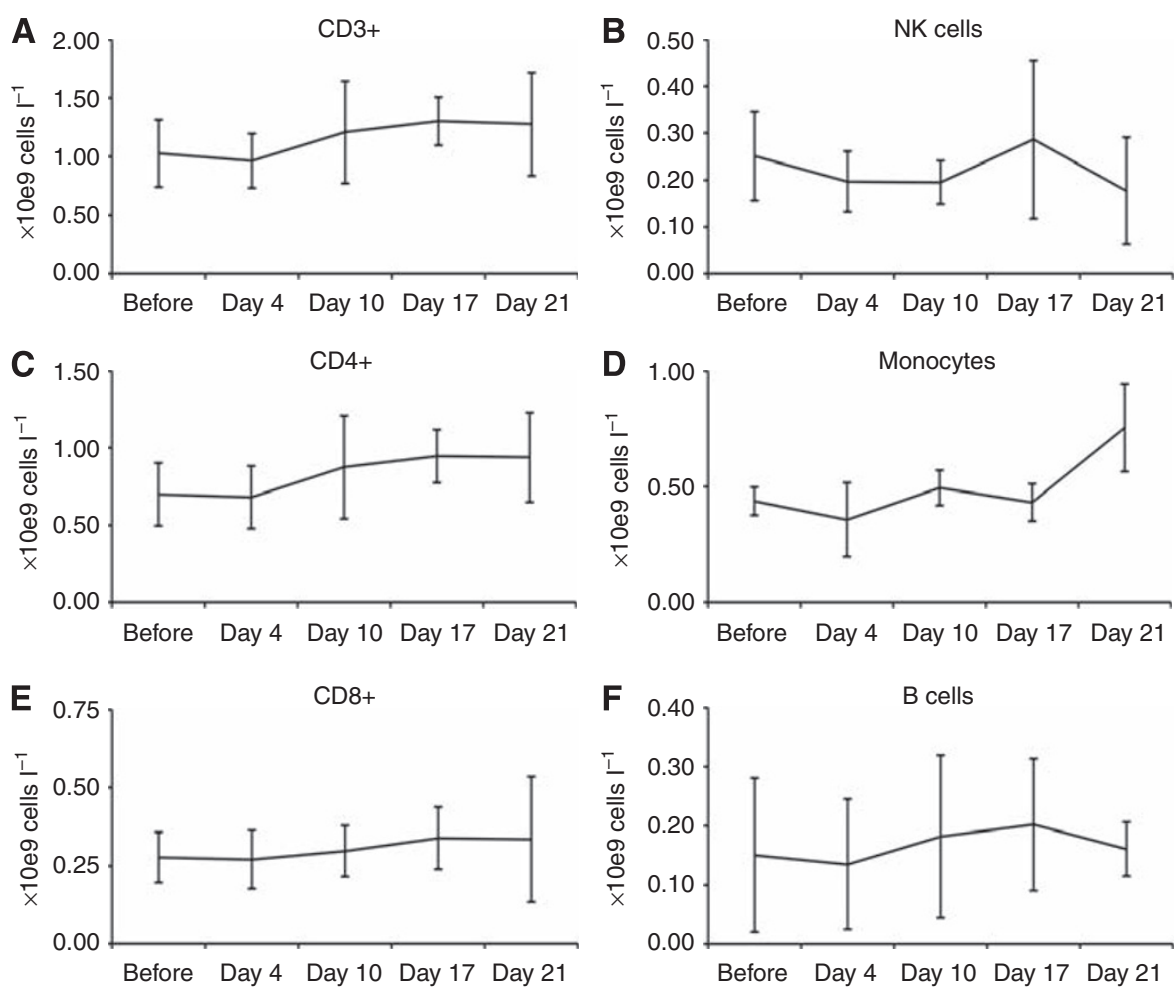

Figure 2 Frequencies of PBMC subsets during treatment with oxaliplatin/capecitabine and DC vaccination. Means with s.d. are depicted. (A) Total T cells

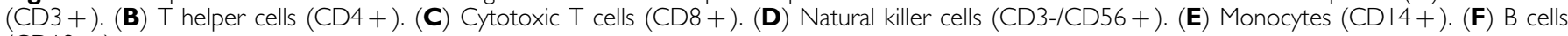
$(\mathrm{CD} \mid 9+)$.

A

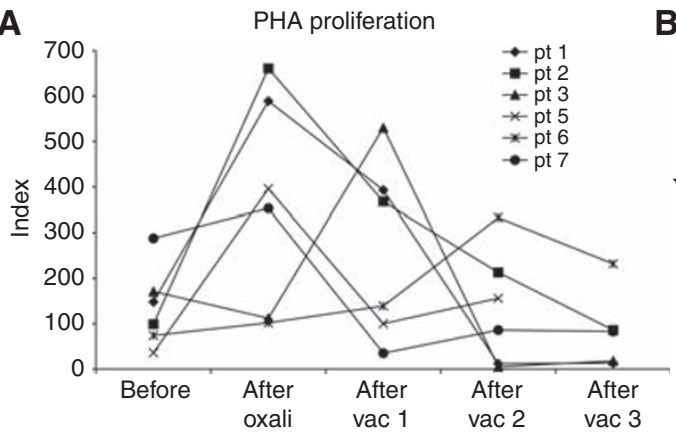

B

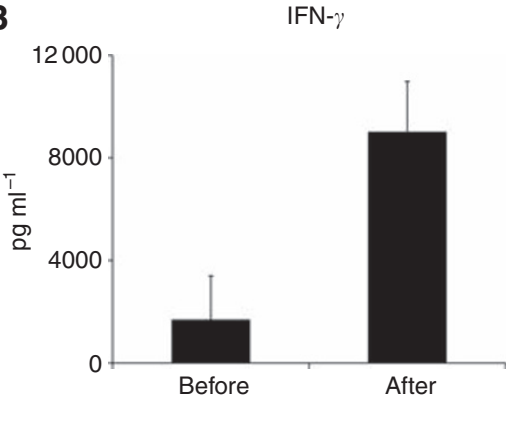

Figure 3 (A) Proliferative non-specific T-cell response upon PHA-stimulation during treatment with oxaliplatin/capecitabine and DC vaccination. In all patients, an increase in proliferation was observed during treatment. (B) Also the IFN- $\gamma$ production upon PHA-stimulation increased during treatment (data of four tested patients are given; the means with s.d. are depicted).
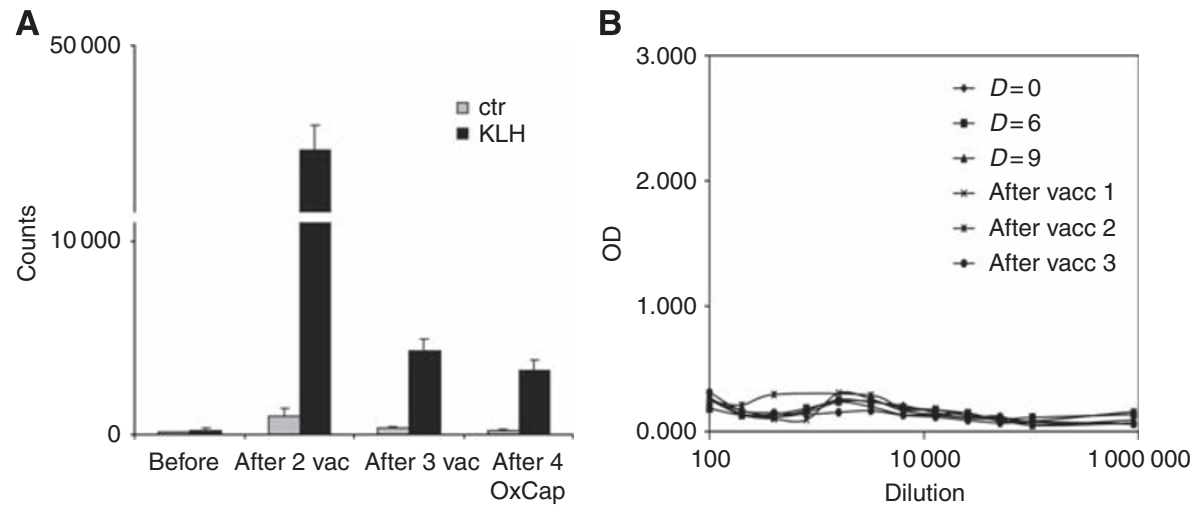

Figure 4 All patients showed a proliferative CD4 + T-cell response against the control antigen $\mathrm{KLH}$. (A) A representative patient (patient 7$)$ is shown. (B) However, B-cell responses against KLH upon vaccination could not be detected in 6 out of 7 patients. 
of tumor antigen-specific immunity. Furthermore, the functionality of the $\mathrm{T}$ cells remained unaffected as they produced high amounts of IFN- $\gamma$ and IL-2 upon co-culture with CEA-loaded target cells (Figure 5B).

\section{DISCUSSION}

Despite ample evidence for chemotherapy-induced immunogenic cell death, much less is known about the effect of chemotherapy on the effector lymphocytes of the immune system in vivo in cancer patients. Therefore, we conducted a clinical pilot trial to test the immunogenicity of a DC vaccine in stage III colon cancer patients treated with standard adjuvant oxaliplatin and capecitabine chemotherapy. We found that robust de novo KLH-specific T-cell responses could very well be induced during the chemotherapy regime. However, B-cell responses were hampered when compared with previous studies using the same vaccine without chemotherapy (de Vries et al, 2003, 2005a). No additional toxicity was observed, apart from the side effects that frequently occur for both treatment strategies separately.

In four out of seven patients, we observed a functional CEAspecific T-cell response upon vaccination with CEA-loaded DCs. Although the number of patients is limited, this is comparable to a previous cohort of colorectal cancer patients that were treated with the same vaccine without chemotherapy (Lesterhuis et al, 2006). To date, none of the treated patients have had a relapse. However, given the adjuvant nature of the treatment, the short follow-up and the limited numbers of patients, no conclusion can be drawn on the clinical efficacy of adding DC vaccination to standard adjuvant chemotherapy. Other studies investigating the combination of immunotherapy and chemotherapy have been performed in colorectal cancer patients. Kaufman and colleagues vaccinated metastatic colorectal cancer patients with a CEA-ALVAC vaccine in combination with irinotecan, 5-FU and leucovorin and found that the CEA-specific T-cell response was unaffected by the

Table I Antigen-specific immune responses

\begin{tabular}{lccccccc}
\hline Patient & I & 2 & $\mathbf{3}$ & $\mathbf{4}$ & $\mathbf{5}$ & $\mathbf{6}$ & $\mathbf{7}$ \\
\hline KLH CD4+ response & + & + & + & + & + & + & + \\
KLH antibody response & - & - & - & - & + & + & - \\
CEA-tetramers peripheral blood & - & - & - & - & - & - & - \\
CEA-tetramers DTH & - & + & nt & - & - & - & + \\
CEA-specific IFN- $\gamma$ response in DTH & + & + & + & - & - & - & + \\
\hline
\end{tabular}

Abbreviations: $\mathrm{CEA}=$ carcinoembryonic antigen; $\mathrm{DTH}=$ delayed type hypersensitivity; IFN = interferon; $\mathrm{KLH}=$ keyhole limpet haemocyanin; $\mathrm{nt}=$ not tested. Summary of all tested $\mathrm{KLH}$ and CEA-specific immune responses upon vaccination and oxaliplatin/ capecitabine treatment chemotherapy (Kaufman et al, 2008). Similar observations were made, using the same chemotherapeutics but different vaccines (Weihrauch et al, 2005; Harrop et al, 2008).

Surprisingly, the non-specific T-cell proliferative capacity increased upon chemotherapy treatment in most patients shortly after infusion of the oxaliplatin. Previously, others had found a similar effect for gemcitabine in a murine model (Nowak et al, 2002), but for platinum-based compounds this has not been reported before. Although oxaliplatin has been described to induce an immunogenic type of cancer cell death, which could result in DC activation and subsequent non-specific T-cell activation (Apetoh et al, 2007; Ghiringhelli et al, 2009), we consider this mechanism less likely in our study as the patients were treated in an adjuvant setting, that is in the absence of macroscopic tumor. A possible explanation for the increased T-cell activation may lie in our recent finding that platinum compounds dephosphorylate signal transducer and activator of transcription 6 (STAT6) (Lesterhuis et al, 2010). This protein is of crucial importance for the induction of $\mathrm{T}$ helper 2 immunity and hence for the development of B-cell responses. Inactivation of STAT6 may result in enhanced $\mathrm{T}$ helper 1 responsiveness and at the same time in decreased B-cell activation, as observed in this study. The fact that we did not find this effect when lymphocytes of healthy donors were stimulated with PHA after $24 \mathrm{~h}$ of culture in the presence of oxaliplatin, suggests that this mechanism mainly works through antigen-presenting cells and not lymphocytes. However, it is questionable whether the in vitro conditions properly mimic the in vivo situation. More research is needed to decipher the exact effects of platinum compounds on immune cells.

Our study is the first to investigate the combined use of specific vaccination with oxaliplatin-based chemotherapy. Oxaliplatin appears to be a promising drug to include in chemoimmunotherapeutic regimens, as it induces an immunogenic type of tumor cell death resulting in enhanced DC activation (Apetoh et al, 2007; Ghiringhelli et al, 2009; Tesniere et al, 2009). Our findings that the immune effector cells remain unaffected and that T-cell proliferative capacity following PHA stimulation even increases upon oxaliplatin treatment further support this strategy.

Although DC vaccinations frequently induce immune responses, objective clinical remissions are rare (Lesterhuis et al, 2008). One possible explanation is that DC vaccination may be more effective in residual microscopic disease, as it lacks a direct cytotoxic effect that is likely required in a macroscopic disease. On the other hand, cytotoxic chemotherapy also does not result in complete tumour eradication in the majority of patients with metastatic solid tumours. Therefore, the combination of DC vaccination with cytotoxic chemotherapy is an attractive strategy. Our data demonstrate the feasibility of the combination of these two strategies and provide the rationale for future studies that investigate the clinical efficacy of this strategy.
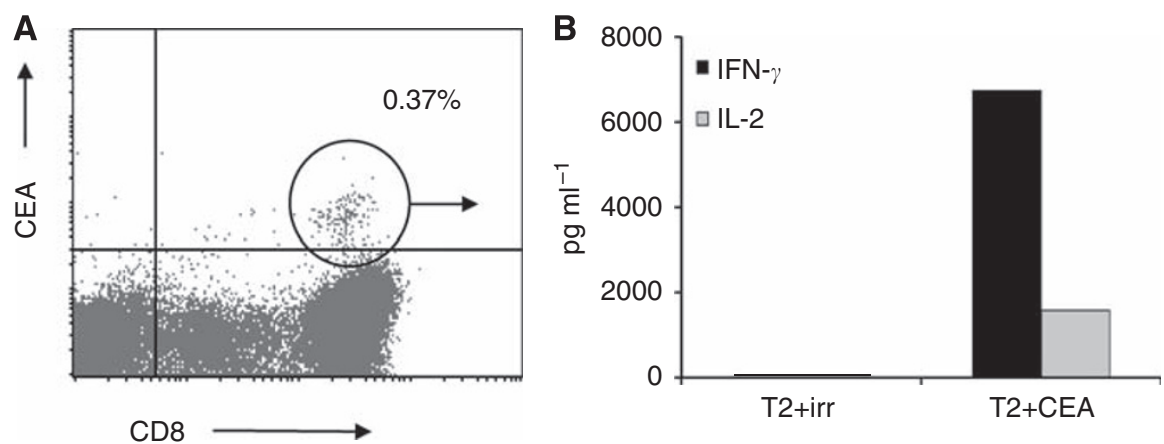

Figure 5 In four out of seven patients, CEA-specific DTH-infiltrating T cells were observed after completion of vaccination, either by $(\mathbf{A})$ tetramer staining or (B) IFN- $\gamma$ and IL-2 release upon co-culture with CEA-loaded target cells. Data from a representative patient (no. 2) are shown. 


\section{ACKNOWLEDGEMENTS}

We kindly thank Christel van Riel, Michel olde Nordkamp, Jeanette Pots and Michelle van Rossum for their assistance. This work was supported by grants from The Netherlands Organization for Scientific Research (92003250) to WJL and the Sascha Swarttouw-Hijmans Foundation.

\section{REFERENCES}

Apetoh L, Ghiringhelli F, Tesniere A, Obeid M, Ortiz C, Criollo A, Mignot G, Maiuri MC, Ullrich E, Saulnier P, Yang H, Amigorena S, Ryffel B, Barrat FJ, Saftig P, Levi F, Lidereau R, Nogues C, Mira JP, Chompret A, Joulin V, Clavel-Chapelon F, Bourhis J, Andre F, Delaloge S, Tursz T, Kroemer G, Zitvogel L (2007) Toll-like receptor 4-dependent contribution of the immune system to anticancer chemotherapy and radiotherapy. Nat Med 13: $1050-1059$

Bourquin C, Schreiber S, Beck S, Hartmann G, Endres S (2006) Immunotherapy with dendritic cells and $\mathrm{CpG}$ oligonucleotides can be combined with chemotherapy without loss of efficacy in a mouse model of colon cancer. Int J Cancer 118: 2790-2795

Correale P, Aquino A, Giuliani A, Pellegrini M, Micheli L, Cusi MG, Nencini C, Petrioli R, Prete SP, De Vecchis L, Turriziani M, Giorgi G, Bonmassar E, Francini G (2003) Treatment of colon and breast carcinoma cells with 5 -fluorouracil enhances expression of carcinoembryonic antigen and susceptibility to HLA-A $\left(^{*}\right) 02.01$ restricted, CEA-peptide-specific cytotoxic $\mathrm{T}$ cells in vitro. Int J Cancer 104: 437-445

Correale P, Cusi MG, Tsang KY, Del Vecchio MT, Marsili S, Placa ML, Intrivici C, Aquino A, Micheli L, Nencini C, Ferrari F, Giorgi G, Bonmassar E, Francini G (2005a) Chemo-immunotherapy of metastatic colorectal carcinoma with gemcitabine plus FOLFOX 4 followed by subcutaneous granulocyte macrophage colony-stimulating factor and interleukin-2 induces strong immunologic and antitumor activity in metastatic colon cancer patients. J Clin Oncol 23: 8950-8958

Correale P, Del Vecchio MT, Di Genova G, Savellini GG, La Placa M, Terrosi C, Vestri M, Urso R, Lemonnier $F$, Aquino A, Bonmassar E, Giorgi G, Francini G, Cusi MG (2005b) 5-fluorouracilbased chemotherapy enhances the antitumor activity of a thymidylate synthase-directed polyepitopic peptide vaccine. J Natl Cancer Inst 97: $1437-1445$

de Vries IJ, Bernsen MR, Lesterhuis WJ, Scharenborg NM, Strijk SP, Gerritsen MJ, Ruiter DJ, Figdor CG, Punt CJ, Adema GJ (2005a) Immunomonitoring tumor-specific $\mathrm{T}$ cells in delayed-type hypersensitivity skin biopsies after dendritic cell vaccination correlates with clinical outcome. J Clin Oncol 23: 5779-5787

De Vries IJ, Bernsen MR, van Geloof WL, Scharenborg NM, Lesterhuis WJ, Rombout PD, Van Muijen GN, Figdor CG, Punt CJ, Ruiter DJ, Adema GJ (2007) In situ detection of antigen-specific T cells in cryo-sections using MHC class I tetramers after dendritic cell vaccination of melanoma patients. Cancer Immunol Immunother 56(10): 1667-1676

de Vries IJ, Eggert AA, Scharenborg NM, Vissers JL, Lesterhuis WJ, Boerman OC, Punt CJ, Adema GJ, Figdor CG (2002) Phenotypical and functional characterization of clinical grade dendritic cells. J Immunother 25: $429-438$

de Vries IJ, Lesterhuis WJ, Barentsz JO, Verdijk P, van Krieken JH, Boerman OC, Oyen WJ, Bonenkamp JJ, Boezeman JB, Adema GJ, Bulte JW, Scheenen TW, Punt CJ, Heerschap A, Figdor CG (2005b) Magnetic resonance tracking of dendritic cells in melanoma patients for monitoring of cellular therapy. Nat Biotechnol 23: $1407-1413$

de Vries IJ, Lesterhuis WJ, Scharenborg NM, Engelen LP, Ruiter DJ, Gerritsen MJ, Croockewit S, Britten CM, Torensma R, Adema GJ, Figdor CG, Punt CJ (2003) Maturation of dendritic cells is a prerequisite for inducing immune responses in advanced melanoma patients. Clin Cancer Res 9: 5091 - 5100

Desoize B, Madoulet C (2002) Particular aspects of platinum compounds used at present in cancer treatment. Crit Rev Oncol Hematol 42: $317-325$

Dudley ME, Wunderlich JR, Robbins PF, Yang JC, Hwu P, Schwartzentruber DJ, Topalian SL, Sherry R, Restifo NP, Hubicki AM, Robinson MR, Raffeld M, Duray P, Seipp CA, Rogers-Freezer L, Morton KE, Mavroukakis SA, White DE, Rosenberg SA (2002) Cancer regression
Conflict of interest

The authors declare no conflict of interest.

Supplementary Information accompanies the paper on British Journal of Cancer website (http://www.nature.com/bjc)

and autoimmunity in patients after clonal repopulation with antitumor lymphocytes. Science 298: $850-854$

Dudley ME, Wunderlich JR, Yang JC, Sherry RM, Topalian SL, Restifo NP, Royal RE, Kammula U, White DE, Mavroukakis SA, Rogers LJ, Gracia GJ, Jones SA, Mangiameli DP, Pelletier MM, Gea-Banacloche J, Robinson MR, Berman DM, Filie AC, Abati A, Rosenberg SA (2005) Adoptive cell transfer therapy following non-myeloablative but lymphodepleting chemotherapy for the treatment of patients with refractory metastatic melanoma. J Clin Oncol 23: 2346-2357

Figdor CG, de Vries IJ, Lesterhuis WJ, Melief CJ (2004) Dendritic cell immunotherapy: mapping the way. Nat Med 10: 475-480

Ghiringhelli F, Apetoh L, Tesniere A, Aymeric L, Ma Y, Ortiz C, Vermaelen K, Panaretakis T, Mignot G, Ullrich E, Perfettini JL, Schlemmer F, Tasdemir E, Uhl M, Genin P, Civas A, Ryffel B, Kanellopoulos J, Tschopp J, Andre F, Lidereau R, McLaughlin NM, Haynes NM, Smyth MJ, Kroemer G, Zitvogel L (2009) Activation of the NLRP3 inflammasome in dendritic cells induces IL-1beta-dependent adaptive immunity against tumors. Nat Med 15: $1170-1178$

Ghiringhelli F, Menard C, Puig PE, Ladoire S, Roux S, Martin F, Solary E, Le Cesne A, Zitvogel L, Chauffert B (2007) Metronomic cyclophosphamide regimen selectively depletes $\mathrm{CD} 4+\mathrm{CD} 25+$ regulatory $\mathrm{T}$ cells and restores $\mathrm{T}$ and $\mathrm{NK}$ effector functions in end stage cancer patients. Cancer Immunol Immunother 56: 641-648

Harrop R, Drury N, Shingler W, Chikoti P, Redchenko I, Carroll MW, Kingsman SM, Naylor S, Griffiths R, Steven N, Hawkins RE (2008) Vaccination of colorectal cancer patients with TroVax given alongside chemotherapy (5-fluorouracil, leukovorin and irinotecan) is safe and induces potent immune responses. Cancer Immunol Immunother 57: $977-986$

Kaufman HL, Lenz HJ, Marshall J, Singh D, Garett C, Cripps C, Moore M, von Mehren M, Dalfen R, Heim WJ, Conry RM, Urba WJ, Benson III AB, Yu M, Caterini J, Kim-Schulze S, Debenedette M, Salha D, Vogel T, Elias I, Berinstein NL (2008) Combination chemotherapy and ALVAC-CEA/ B7.1 vaccine in patients with metastatic colorectal cancer. Clin Cancer Res 14: 4843 - 4849

Lake RA, Robinson BW (2005) Immunotherapy and chemotherapy-a practical partnership. Nat Rev Cancer 5: 397-405

Lesterhuis WJ, Aarntzen EH, De Vries IJ, Schuurhuis DH, Figdor CG, Adema GJ, Punt CJ (2008) Dendritic cell vaccines in melanoma: from promise to proof? Crit Rev Oncol Hematol 66: 118-134

Lesterhuis WJ, de Vries IJ, Schuurhuis DH, Boullart AC, Jacobs JF, de Boer AJ, Scharenborg NM, Brouwer HM, van de Rakt MW, Figdor CG, Ruers TJ, Adema GJ, Punt CJ (2006) Vaccination of colorectal cancer patients with CEA-loaded dendritic cells: antigen-specific T cell responses in DTH skin tests. Ann Oncol 17: 974-980

Lesterhuis WJ, Punt CJA, Eleveld-Trancikova D, Jansen BJH, Schreibelt G, De Boer A, Adema GJ, Figdor CG, De Vries IJM (2010) Platinum anti-cancer drugs attenuate $\mathrm{T}$ cell-mediated immune suppression through STAT6/PD-L2. In Proceedings of the 101st Annual Meeting of the American Association of Cancer Research 2010, April 17-21; Washington, DC, Philadelphia (PA): AACR; 2010. Abstract 4381

Mullins DW, Sheasley SL, Ream RM, Bullock TN, Fu YX, Engelhard VH (2003) Route of immunization with peptide-pulsed dendritic cells controls the distribution of memory and effector $\mathrm{T}$ cells in lymphoid tissues and determines the pattern of regional tumor control. $J$ Exp Med 198: $1023-1034$

Nistico P, Capone I, Palermo B, Del Bello D, Ferraresi V, Moschella F, Arico E, Valentini M, Bracci L, Cognetti F, Ciccarese M, Vercillo G, Roselli M, Fossile E, Tosti ME, Wang E, Marincola F, Imberti L, Catricala C, Natali PG, Belardelli F, Proietti E (2008) Chemotherapy enhances vaccine-induced antitumor immunity in melanoma patients. Int J Cancer 124: $130-139$ 
Nowak AK, Robinson BW, Lake RA (2002) Gemcitabine exerts a selective effect on the humoral immune response: implications for combination chemo-immunotherapy. Cancer Res 62: $2353-2358$

Obeid M, Tesniere A, Ghiringhelli F, Fimia GM, Apetoh L, Perfettini JL, Castedo M, Mignot G, Panaretakis T, Casares N, Metivier D, Larochette N, van Endert P, Ciccosanti F, Piacentini M, Zitvogel L, Kroemer G (2007) Calreticulin exposure dictates the immunogenicity of cancer cell death. Nat Med 13: 54-61

Tesniere A, Schlemmer F, Boige V, Kepp O, Martins I, Ghiringhelli F, Aymeric L, Michaud M, Apetoh L, Barault L, Mendiboure J, Pignon JP, Jooste V, van Endert P, Ducreux M, Zitvogel L, Piard F, Kroemer G
(2009) Immunogenic death of colon cancer cells treated with oxaliplatin. Oncogene 29: 482-491

Tsang KY, Zaremba S, Nieroda CA, Zhu MZ, Hamilton JM, Schlom J (1995) Generation of human cytotoxic $\mathrm{T}$ cells specific for human carcinoembryonic antigen epitopes from patients immunized with recombinant vaccinia-CEA vaccine. J Natl Cancer Inst 87: 982 - 990

Weihrauch MR, Ansen S, Jurkiewicz E, Geisen C, Xia Z, Anderson KS, Gracien E, Schmidt M, Wittig B, Diehl V, Wolf J, Bohlen H, Nadler LM (2005) Phase I/II combined chemoimmunotherapy with carcinoembryonic antigen-derived HLA-A2-restricted CAP-1 peptide and irinotecan, 5 -fluorouracil, and leucovorin in patients with primary metastatic colorectal cancer. Clin Cancer Res 11: 5993-6001 